\title{
Co-factor regeneration in the production of 1,2-epoxypropane by Mycobacterium strain E3: the role of storage material
}

\author{
André de HaAn, ${ }^{*}$ Mark R. Smith, Wilfried G. B. Voorhorst and Jan A. M. de Bont \\ Division of Industrial Microbiology, Department of Food Science, Wageningen Agricultural University, PO Box 8129, \\ 6700 EV Wageningen, The Netherlands
}

(Received 22 July 1993; accepted 27 August 1993)

\begin{abstract}
When grown on ethene Mycobacterium strain E3 produces epoxyalkanes from alkenes in an oxygen- and NADHdependent reaction. The process of co-factor regeneration was studied by analysing the intracellular pools of NADH and storage material during the production of 1,2-epoxypropane from propene. With the depletion of NADH the production of 1,2-epoxypropane stopped. NADH could be regenerated from the oxidation of added cosubstrate or from oxidation of storage material. Cells cultivated in chemostat culture under nitrogen limitation produced more 1,2-epoxypropane compared to cells cultivated under carbon limitation, due to their higher content of storage material. Addition of glucose to cells grown under carbon limitation stimulated the formation of 1,2epoxypropane. The uptake of glucose resulted in the accumulation of storage material, which was utilized after depletion of the glucose. Glycogen and trehalose were the preferred forms of storage material used for co-factor regeneration. From the results it was concluded that formation and utilization of storage material play a crucial role in the process of co-factor regeneration in Mycobacterium strain E3.
\end{abstract}

\section{Introduction}

Mycobacterium strain E3 was isolated on ethene by Habets-Crützen et al. (1984). The degradation of ethene is initiated by a mono-oxygenase enzyme (Hartmans et al., 1991; Weber et al., 1992) that oxidizes ethene to 1,2epoxyethane in an NADH- and oxygen-dependent reaction. In contrast to the mono-oxygenase, the epoxyalkane-degrading system present in the organism has a very high substrate specificity and 1,2epoxypropane and higher epoxyalkanes are not degraded. Ethene-grown cells, therefore, accumulate these epoxyalkanes when incubated with the corresponding alkenes (Habets-Crützen et al., 1984; van Ginkel et al., 1987). Regeneration of the co-factor NADH can be achieved using whole-cell incubations with in vivo regeneration by the oxidation of intracellular storage materials or by the oxidation of added co-substrate. Production of epoxides using a co-substrate has been optimized for several micro-organisms (Aisaka et al., 1992; Furuhashi \& Takagi, 1984; Johnstone et al., 1987; Stirling \& Dalton, 1979), although detailed information concerning the metabolic fate of the added co-substrate and how it exerts its effect on the amount of epoxide produced is not available. Previous studies with immobil-

* Author for correspondence. Fax +31837084978 . ized cells showed that the amount of epoxyalkane produced by Mycobacterium strain E3 could also be increased by the addition of co-substrates (HabetsCrützen \& de Bont, 1987; Smith et al., 1993). The role of storage material, however, was not investigated. Mycobacteria are known to accumulate high levels of storage material. In combination with their slow metabolism, these high levels of storage material are assumed to play an important role in the observed high longevity of mycobacteria under starvation conditions (Ratledge, 1982). Storage materials reported in mycobacteria, functioning as reserve materials, include lipid, glycogen and trehalose (Antoine \& Tepper, $1969 a, b$; Elbein \& Mitchell, 1973; Winder \& Rooney, 1970). Utilization of the type of storage material, however, was found to be very dependent on the reaction conditions used.

In the present investigation the fate of the added co-substrate and the possible involvement of storage materials in epoxide production was studied in more detail. For this purpose the production of 1,2epoxypropane from propene by Mycobacterium strain E3 was selected.

\section{Methods}

Organism and growth. Mycobacterium strain E3 (Habets-Crützen et al., 1984) was cultivated continuously as described previously (HabetsCrützen \& de Bont, 1987) in 1 litre of mineral medium (Wiegant \& de 
Bont, 1980) in a 2 litre Applikon fermenter at $D=0.02 \mathrm{~h}^{-1}$ under carbon limitation $\left(\mathrm{NH}_{4} \mathrm{Cl}, 2 \cdot 0 \mathrm{~g} \mathrm{l}^{-1}\right)$ or nitrogen limitation $\left(\mathrm{NH}_{4} \mathrm{Cl}\right.$, $\left.0.3 \mathrm{gl}^{-1}\right)$. The carbon source was supplied mixed in with the air $\left(100 \mathrm{~cm}^{3}\right.$ $\left.\min ^{-1}\right)$, which contained $2 \%(\mathrm{v} / \mathrm{v})$ ethene (carbon limitation) or $10 \%$ (v/v) ethene (nitrogen limitation). Limitations were checked by showing that an increase in concentration of the limiting nutrient resulted in an increase in the biomass concentration. Dissolved oxygen levels were monitored with a Clark-type oxygen electrode and were always above $40 \%$ air saturation. $\mathrm{CO}_{2}$ formation was continuously monitored in the outlet gas using a Beckman infra-red $\mathrm{CO}_{2}$-analyser.

Preparation of washed cell suspensions. After reaching a constant biomass concentration and $\mathrm{CO}_{2}$ formation rate the fermenter was run for at least six volume changes. Based on the constant $\mathrm{CO}_{2}$ concentration in the outlet gas the culture was considered to be in a steady state. The cells from the chemostat were harvested at $16000 \mathrm{~g}$ at $4{ }^{\circ} \mathrm{C}$, washed with $50 \mathrm{~mm}$-HEPES/NaOH buffer $\mathrm{pH} 7.0$ (buffer $\mathrm{A}$ ) and then resuspended in buffer $A$. In all experiments freshly harvested cells were used.

Experimental procedures. Reactions were carried out with washed cell suspensions in sealed serum bottles $(35 \mathrm{ml})$ containing $3 \mathrm{ml}$ of buffer A. The bottles always contained $0.7 \mathrm{mg}$ cellular protein. Substrate $(200 \mu \mathrm{mol})$ was added by replacing $5 \mathrm{ml}$ of the gas phase with $5 \mathrm{ml}$ of propene. When required $5 \mathrm{~mm}$-glucose was added as a cosubstrate. For the determination of storage material a larger scale was necessary to obtain enough biomass for an accurate analysis. For this purpose 1 litre serum bottles were used with a final volume of $130 \mathrm{ml}$ of buffer A, $30 \mathrm{mg}$ cellular protein and $200 \mathrm{ml}$ propene. In addition 150 $\mathrm{ml}$ of air was replaced by pure oxygen to prevent oxygen limitation. The bottles were incubated in a shaking water-bath at $30^{\circ} \mathrm{C}$. Samples were prepared by rapidly cooling the bottles on ice followed by harvesting and washing with demineralized water as described above. The resulting cell suspension was freeze-dried overnight for further analysis. All experiments were repeated at least three times. Unless stated otherwise, representative results are shown.

\section{Analytical procedures}

1,2-epoxypropane. The concentration of 1,2-epoxypropane was determined by analysing head-space samples on a Packard 430 gas chromatograph with a Porapak R column (Hartmans et al., 1991).

$\mathrm{CO}_{2}$. The evolution of $\mathrm{CO}_{2}$ was measured using a Packard 427 gas chromatograph fitted with a TCD $\left(140^{\circ} \mathrm{C}\right)$. The column (Hayesep Q) was maintained at $110^{\circ} \mathrm{C}$ and helium used as the carrier gas $(30 \mathrm{ml}$ $\min ^{-1}$ ). The injector port was held at $100^{\circ} \mathrm{C}$.

Glucose determination. Glucose was determined using either the Peridochrom glucose kit or the glucose/fructose kit (both from Boehringer Mannheim).

Protein determination. Protein content of cell-free extracts was determined according to the method of Bradford (1976) with bovine serum albumin as a standard. For whole cells the protein was first extracted by the method of Habets-Crützen et al. (1984). To express levels of storage material in terms of $\mathrm{mg}(\mathrm{mg} \text { protein })^{-1}$, the value for protein obtained from cell-free extracts was used.

Total lipid content. Lipids were extracted from freeze-dried cells by the method of Burdon (1986). The extract was transferred into a preweighed vial and dried in a vacuum desiccator to constant weight.

Carbohydrate analysis. Total carbohydrates, glycogen and trehalose were determined in cell-free extracts. Extracts were prepared by sonifying freeze-dried cells $\left(10 \mathrm{~min}, 0^{\circ} \mathrm{C}\right)$. These extracts contain all the free carbohydrates. Prior to analysis the extracts were heat-treated (10 min, $100{ }^{\circ} \mathrm{C}$ ) to stop any enzymic activity interfering with the assays.

Total carbohydrates. The anthrone method described by Seifter $e t$ al. (1950) was used with glucose as a standard.
Glycogen. The glycogen content was determined enzymically by the method of Passonneau et al. (1967) with the inclusion of the debranching enzyme isoamylase $\left(0.6 \mathrm{U} \mathrm{ml}^{-1}\right)$ from Pseudomonas amyloderamosa (Yokobayashi, 1970). Glycogen from yeast was used as a standard.

Trehalose. The trehalose content was determined enzymically as described by van Urk et al. (1989). The amount of glucose present after and before the addition of trehalase was determined enzymically with the glucose/fructose kit (Boehringer Mannheim). The Peridochrom kit could not be used in this case because of interference by trehalose. The trehalose content was calculated using as a standard trehalose from yeast (Sigma).

$N A D H$. Samples $(2 \mathrm{ml})$ were taken from the incubations, very rapidly cooled to $0^{\circ} \mathrm{C}$ and $1 \mathrm{ml}$ of ice-cold $3 \mathrm{M}-\mathrm{KOH}$ was added very slowly. The suspension was incubated at $50{ }^{\circ} \mathrm{C}$ for $10 \mathrm{mins}$ and then cooled again on ice. The extract was neutralized by slowly adding icecold $3 \mathrm{M}-\mathrm{HCl}$. After spinning down the cell debris the extract was immediately analysed. NADH was analysed using a Separations HPLC system (Ambacht, NL). Two Chromsep Chromspher $\mathrm{C}_{18}$ columns $(2 \times 10 \mathrm{~cm})$ were isocratically eluted using a mobile phase consisting of $0.08 \mathrm{M}-\mathrm{KH}_{2} \mathrm{PO}_{4} / \mathrm{KOH}, \mathrm{pH} 7 \cdot 0$, containing $5 \%(\mathrm{v} / \mathrm{v}) \mathrm{CH}_{3} \mathrm{CN}$ at a flow rate of $0.5 \mathrm{ml} \mathrm{min}^{-1}$. Reduced nicotinamide levels were determined using a UV detector at $254 \mathrm{~nm}$ and quantified using an external standard. The retention time of NADH was $4.1 \mathrm{~min}$.

Chemicals. Ethene and propene were of commercial purity and obtained from Hoekloos (Schiedam, NL). All other chemicals used were of analytical grade.

\section{Results}

Production of 1,2-epoxypropane and $\mathrm{CO}_{2}$ in the absence of co-substrate

Mycobacterium strain E3 was grown in chemostat culture with ethene as carbon and energy source, under both carbon and nitrogen limitation. Cells were harvested from the chemostat, washed in HEPES buffer and incubated with propene. The formation of both 1,2epoxypropane and $\mathrm{CO}_{2}$ was monitored for $2 \mathrm{~d}$. Cells grown under nitrogen limitation produced approximately three times as much 1,2-epoxypropane as cells grown under carbon limitation (Fig. 1). These nitrogenlimited (growing) cells also produced more $\mathrm{CO}_{2}$ than the ethene-limited cells (Fig. 1)

\section{Utilization of storage materials in the absence of co-substrate}

Cells were analysed for storage materials to investigate if the increased production of 1,2-epoxypropane and $\mathrm{CO}_{2}$ by cells cultivated under nitrogen limitation could be ascribed to the utilization of intracellular reserve materials (Fig. 2). Cells cultivated under nitrogen limitation contained a 10 -fold higher concentration of intracellular glycogen than cells grown under carbon limitation, whilst the trehalose concentration was the same. The lipid content of the cells was slightly increased under nitrogen limitation. Subsequently, changes in the 


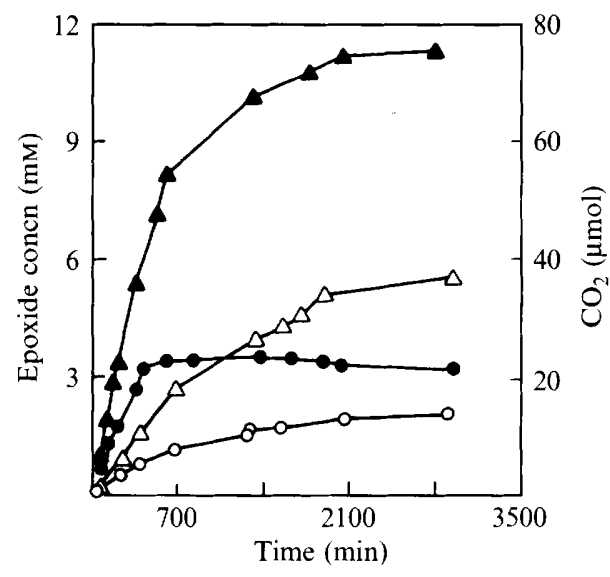

Fig. 1

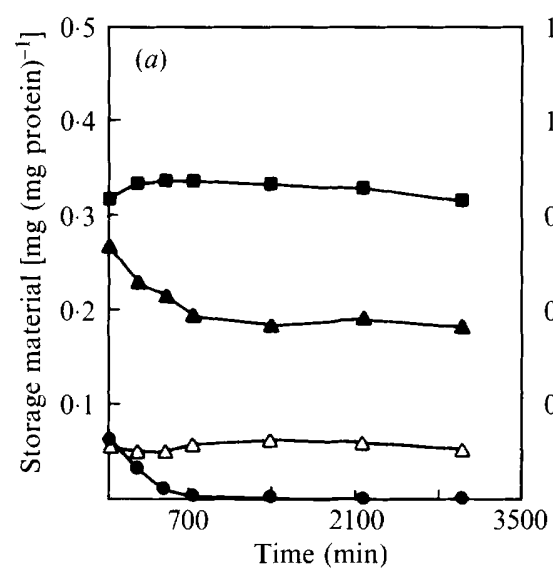

Fig. 2

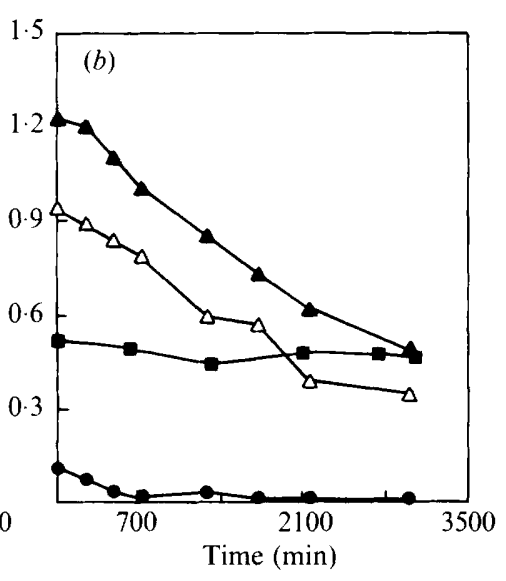

Fig. 1. Production of 1,2-epoxypropane and $\mathrm{CO}_{2}$ by washed cells of Mycobacterium strain E3. Cells were grown in chemostat culture under carbon $(\boldsymbol{O}, \bigcirc)$ or nitrogen limitation $(\mathbf{\Delta}, \Delta)$ and production of 1,2-epoxypropane $(\boldsymbol{O}, \mathbf{\Delta})$ and $\mathrm{CO}_{2}(O, \Delta)$ was followed with time.

Fig. 2. Changes in the levels of storage material in resting washed whole cells from chemostat cultures of Mycobacterium strain E3, cultivated on ethene, during incubation with propene. ( $a$ ) Cultivated under carbon limitation; $(b)$ cultivated under nitrogen limitation. $\triangle$, Glycogen; $\boldsymbol{\bullet}$, trehalose; $\boldsymbol{\Delta}$, total carbohydrates; $\boldsymbol{\square}$, lipid.

levels of storage materials that took place during incubation of the washed cells in the presence of propene were monitored (Fig. 2). In cells grown under carbon limitation trehalose was rapidly used but glycogen was not used at all (Fig. $2 a$ ). The changes in the content of total carbohydrates confirmed that trehalose was the only carbohydrate used during the incubations. The lipid content of the cells was constant. Trehalose was also rapidly metabolized in cells grown under nitrogen limitation, but in this case glycogen was used as well (Fig. $2 \mathrm{~b}$ ). Glycogen and trehalose were the only carbohydrates used, as confirmed by the changes in the content of total carbohydrates. Despite the relatively high lipid content of the cells grown under nitrogen limitation, no utilization of lipids could be detected during the reaction.

\section{Production of 1,2-epoxypropane in the presence of co-substrate}

The 1,2-epoxypropane produced by cells grown under nitrogen limitation was only slightly affected by the addition of external energy sources. However, glucose and other energy sources (e.g. glycerol, acetate and ethanol) strongly enhanced 1,2-epoxypropane production in cells grown under carbon limitation. Consequently, the effect of a co-substrate was studied in more detail using cells grown under carbon limitation. Addition of glucose $(5 \mathrm{~mm})$ resulted in a 5 -fold increase in the amount of 1,2-epoxypropane produced (Fig. 3), as compared to incubation without a co-substrate (Fig. 1). Monitoring the uptake of glucose (Fig. $3 a$ ) revealed that the stimulation of 1,2-epoxypropane formation continued after exhaustion of the glucose from the medium. Analysis of the levels of storage material during the incubation showed that storage material was initially formed and subsequently utilized (Fig. 3 b). In particular, glycogen showed a large initial increase in concentration, but it was utilized again after exhaustion of the glucose. Trehalose levels were also initially enhanced but only to a minor extent, and went down to almost zero after exhaustion of the glucose. No significant changes could be observed in the lipid content of the cells during the incubation time.

Effect of the level of NADH on the formation of 1,2epoxypropane

The central question was if the depletion of storage materials with time would also affect the intracellular level of NADH, which is required for 1,2-epoxypropane production. Therefore, the changes in the level of NADH in cells grown under carbon limitation were measured during the incubations with propene. The level of NADH dropped to almost zero within $12 \mathrm{~h}$, coinciding with the disappearance of trehalose from the cells (Fig. $2 a$ ) and cessation of the production of 1,2-epoxypropane (Fig. 1). If glucose was added to the cells, the level of NADH initially increased rapidly. This level eventually dropped, but NADH remained at an elevated level even after glucose was fully consumed. 


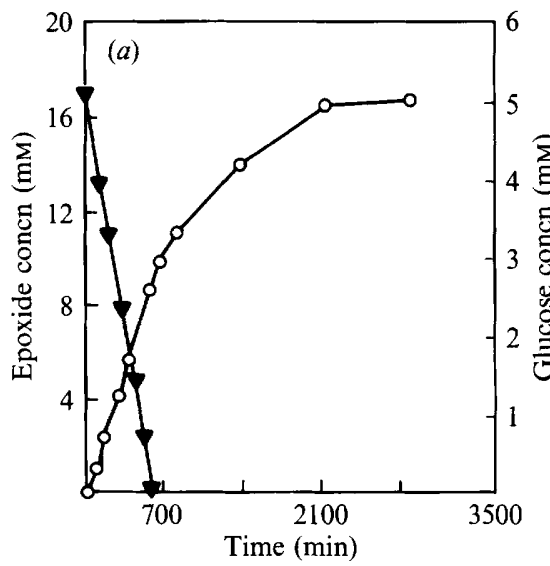

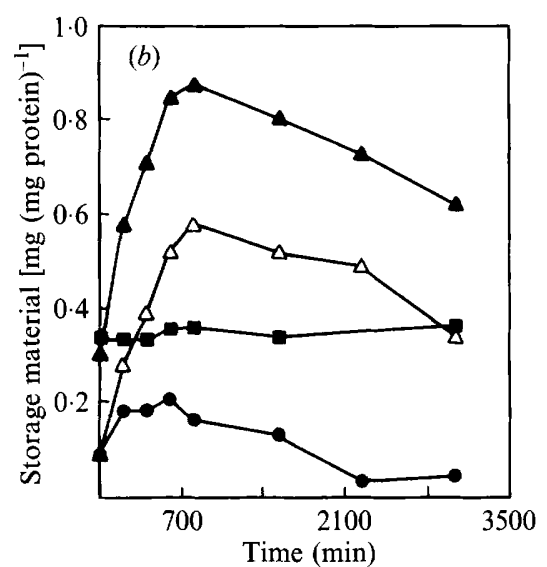

Fig. 3

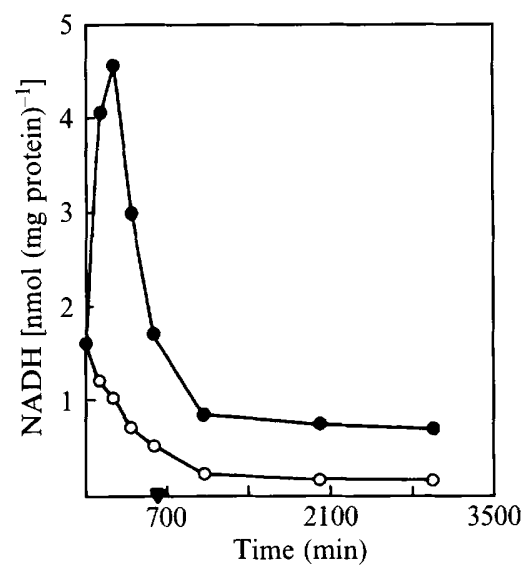

Fig. 4

Fig. 3. Effect of the addition of $5 \mathrm{~mm}$-glucose on the production of $(a)$ 1,2-epoxypropane and $\mathrm{CO}_{2}$, and $(b)$ utilization of storage material by washed cells of Mycobacterium strain E3. Cells were grown in chemostat culture under carbon limitation. O, 1,2-Epoxypropane; $\boldsymbol{\nabla}$, glucose; $\triangle$, glycogen; $\boldsymbol{O}$, trehalose; $\boldsymbol{\Delta}$, total carbohydrates; $\boldsymbol{\square}$, lipid.

Fig. 4. Changes in the intracellular level of NADH of resting washed cells of Mycobacterium strain E3. Cells were cultivated in a chemostat on ethene under carbon limitation and were incubated in the presence of propene. $\bigcirc$, No co-substrate;, 5 mM-glucose added. $\boldsymbol{\nabla}$, Point of glucose exhaustion.

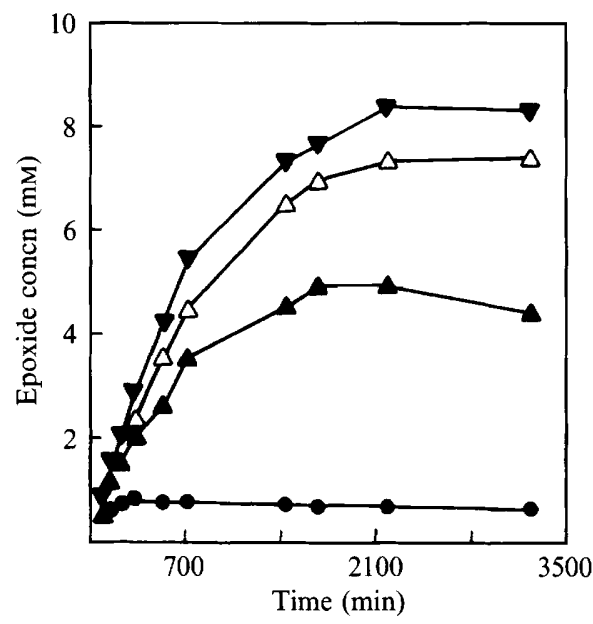

Fig. 5. Effect of the removal of previously produced 1,2-epoxypropane on the production of additional 1,2-epoxypropane by Mycobacterium strain E3. Cells were pre-incubated with propene in the presence and absence of $5 \mathrm{mM}$-glucose and, after washing with HEPES buffer, subsequently incubated with propene in the presence or absence of 5 mM-glucose. $\boldsymbol{\Delta}$, Pre-incubated with glucose, prolonged without glucose; $\mathbf{\nabla}$, pre-incubated with glucose, prolonged with glucose; $\boldsymbol{\bullet}$ pre-incubated without glucose, prolonged without glucose; $\triangle$, preincubated without glucose, prolonged with glucose.

\section{Limiting factors in the production of 1,2-epoxypropane}

The analysis of the levels of storage materials present showed that cells incubated in the presence of glucose still contained an increased level of storage material and an increased level of NADH at the end of a $50 \mathrm{~h}$ incubation in the presence of propene (Figs 3 and 4).
However, formation of 1,2-epoxypropane had already stopped. Supplying additional glucose to such cells did not result in the formation of additional 1,2epoxypropane. Therefore, the possible inhibitory effect of the 1,2-epoxypropane accumulated after $50 \mathrm{~h}$ incubation was tested by removing the 1,2-epoxypropane by washing the cells with HEPES buffer. These washed cells were incubated again with propene in the presence and absence of glucose. A significant amount of new 1,2epoxypropane was formed, even without the addition of glucose (Fig. 5). In contrast to this, cells that had been incubated for $50 \mathrm{~h}$ without a co-substrate (Fig. 1) produced almost no additional 1,2-epoxypropane after removal of the accumulated 1,2-epoxypropane unless glucose was added (Fig. 5).

\section{Discussion}

Formation of 1,2-epoxypropane in the absence of a co-substrate

In the absence of a co-substrate the amount of 1,2epoxypropane produced was clearly dependent on the cultivation conditions used. Analysis of the levels of storage materials showed that the increased production of 1,2-epoxypropane by cells grown under nitrogen limitation could be explained by the higher levels of storage materials present in these cells. Although the role of trehalose as a storage material is under much debate (van Laere, 1989), both glycogen and trehalose appeared to be readily mobilizable forms of storage material in 
Mycobacterium strain E3. Under carbon limitation the levels of trehalose and glycogen in Mycobacterium strain E3 were similar, with only the glycogen level increasing when changing to nitrogen limitation. Similar observations were made by Elbein \& Mitchell (1973) for Mycobacterium smegmatis. Their experiments indicated that although the level of trehalose did not change, it was constantly used and synthesized whereas glycogen was turned over at a much lower rate. Elbein \& Mitchell (1973) suggested that in growing cells trehalose only had a structural role and glycogen served as a storage material. In contrast, the trehalose present in $\mathrm{Myco}^{-}$ bacterium strain E3 clearly functioned as a storage material, as it was utilized to regenerate the NADH needed for the production of 1,2-epoxypropane. The low level of glycogen present in cells grown under carbon limitation apparently only played a structural role, as it was not utilized. The lipid and glycogen content of Mycobacterium phlei and Mycobacterium tuberculosis was reported to increase to values over $20 \%$ (w/w, cell dry wt) during post-exponential growth in nitrogenlimited medium (Antoine \& Tepper, $1969 a, b$ ). Mycobacterium strain E3 also accumulated glycogen and lipid under nitrogen limitation but to a minor extent. Growing cells apparently accumulate less storage material than non-growing cells. The stored glycogen and trehalose were utilized resulting in increased production of 1,2epoxypropane. Surprisingly, lipids accumulated in cells grown under nitrogen limitation were not used during the incubations (Fig. 2 b). Antoine \& Tepper (1969 a) reported that lipids could be used as an endogenous reserve material by Mycobacterium phlei to produce new cell material. Lipid, however, was only utilized after depletion of glycogen. At the end of our incubations the glycogen was not depleted and this could be the reason that the lipid was not used.

\section{Formation of 1,2-epoxypropane in the presence of a co-substrate}

Many groups (Furuhashi, 1986; Johnstone et al., 1987) have reported on the addition of glucose as a cosubstrate for the regeneration of NADH to produce more epoxide. Our results show that for Mycobacterium strain E3 the glucose is not just simply oxidized to $\mathrm{CO}_{2}$, but is partly converted into storage material which can be used after depletion of the glucose. Glycogen appeared to be the preferred form of storage material. As observed in chemostat culture the level of trehalose is apparently under more strict metabolic control, whereas additional lipid was not formed. From Fig. 3 it is clear that the cells at the end of these incubations still contained an excess of storage materials and that the formation of 1,2epoxypropane was not limited by the depletion of storage material. The high concentration of 1,2-epoxypropane present inhibited the mono-oxygenase reaction (HabetsCrützen \& de Bont, 1985). This could be clearly demonstrated by showing that after removal of the 1,2epoxypropane the cells started producing 1,2epoxypropane again (Fig. 5).

\section{Effect of the level of NADH on the formation of 1,2-epoxypropane}

The pool of NADH in cells is too small to account for any significant production of 1,2-epoxypropane. The amount of 1,2-epoxypropane that can be produced is, therefore, dependent on regeneration of this co-factor. Measuring absolute values of metabolites like NADH in mycobacteria is very difficult (Ratledge, 1982). The measured values, therefore, are difficult to interpret in terms of effect on reaction rates. The changes in these levels, however, indicated that NADH can indeed be the limiting step in the production of 1,2-epoxypropane. In the absence of a co-substrate the pool of NADH has to be regenerated from the oxidation of storage material. Comparison of the plots of storage material, NADH and 1,2-epoxypropane (Figs 1, 2a and 4) clearly shows that with the depletion of trehalose the concentration of NADH drops to almost zero and as a consequence the production of 1,2-epoxypropane stops. The co-factor NADH could also be regenerated from the oxidation of a co-substrate. Again, however, storage material played a key role in this process. Due to the utilization of accumulated storage material the level of NADH was maintained at an increased level. This level may be held responsible for the continued production of 1,2epoxypropane after the exhaustion of the co-substrate. It is also clear that the amount of 1,2-epoxypropane produced in this case was not limited by the depletion of the co-factor NADH.

Our results have shown that co-factor regeneration in Mycobacterium strain E3 is a complex process. Formation and utilization of storage materials are key events in this process. As a consequence, the amount of epoxyalkane produced will strongly depend on the physiological status of the cells. A careful evaluation of the epoxide-producing potential of different strains can, therefore, be made only if this is taken into account.

\section{References}

ANTOINE, A. D. \& TePPER, B. S. (1969a). Environmental control of glycogen and lipid content of Mycobacterium phlei. Journal of General Microbiology 55, 217-226.

Antorne, A. D. \& TePper, B. S. (1969b). Environmental control of glycogen and lipid content of Mycobacterium tuberculosis. Journal of Bacteriology 100, 538-539.

Aisaka, K., Ohshiro, T \& Uwajima, T. (1992). Optimum culture conditions for the epoxidation of cis-propenylphosphonate to 
fosfomycin by Cellvibrio gilvus. Applied Microbiology and Biotechnology 36, 431-435.

BRADFORD, M. M. (1976). A rapid and sensitive method for the quantification of microgram quantities of protein utilizing the principle of protein-dye binding. Analytical Biochemistry 72, 248-254.

Burdon, R. H. (1986). Techniques of lipidology; isolation, analysis and identification of lipids. In Laboratory Techniques in Biochemistry and Molecular Biology, pp. 100-111. Edited by R. H. Burdon \& R. H. van Knippenberg. Amsterdam: Elsevier.

Elbein, A. D. \& Mitchell, M. (1973). Levels of glycogen and trehalose in Mycobacterium smegmatis and the purification and properties of the glycogen synthetase. Journal of Bacteriology 113, 863-873.

FURUHASH, K. (1986). A fermentation process for the production of optically active epoxides. Chemical Economy and Engineering Review $18,21-26$.

Furuhashi, K. \& TAKaGi, M. (1984). Optimization of a medium for the production of 1,2-epoxytetradecane by Nocardia corallina B276. Applied Microbiology and Biotechnology 20, 6-9.

van Ginkel, C. G., Welten, H. G. J. \& de Bont, J. A. M. (1987). Oxidation of gaseous and volatile hydrocarbons by selected alkeneutilizing bacteria. Applied and Environmental Microbiology 53, 2903-2907.

Habets-Crützen, A. Q. H., Brink, L. E. S., van Ginkel, C. G., DF Bont, J. A. M. \& Tramper, J. (1984). Production of epoxides from gaseous alkenes by resting-cell suspensions and immobilized cells of alkene-utilizing bacteria. Applied Microbiology and Biotechnology 20, 245-250.

HABETS-CRÜTZEN, A. Q. H. \& DE BonT, J. A. M. (1985). Inactivation of alkene oxidation by epoxides in alkene- and alkane-grown bacteria. Applied Microbiology and Biotechnology 22, 428-433.

HaBETS-CRÜTZEN, A. Q. H. \& DE BONT, J. A. M. (1987). Effect of various co-substrates on 1,2-epoxypropane formation from propene by ethene-utilizing mycobacteria. Applied Microbiology and Biotechnology 26, 434-438.

Hartmans, S., Weber, F. J., Somhorst, D. P. M. \& de Bont, J. A. M. (1991). Alkene monooxygenase from Mycobacterium: a multicomponent enzyme. Journal of General Microbiology 137, 2550-2560.
Johnstone, S. L., Phillips, G. T., Robertson, B. W., Watts, P. D., Bertola, M. A., Koger, H. S. \& Marx, A. F. (1987). Stereoselective synthesis of $S-(-)-\beta$-blockers via microbially produced epoxide intermediates. In Biocatalysis in Organic Media, pp. 387-392. Edited by C. Laane, J. Tramper \& M. D. Lilly. Amsterdam: Elsevier.

VAN LAERE, A. (1989). Trehalose, reserve and/or stress metabolite? FEMS Microbiology Reviews 63, 201-210.

Passonneau, J. V., Gatfield, P. D., Schultz, D. W. \& Lowry O. H. (1967). An enzymatic method for measurement of glycogen. Analytical Biochemistry 19, 315-326.

RATLEDGE, C. (1982). Nutrition, growth and metabolism. In The Biology of the Mycobacteria, vol. 1, pp. 185-274. Edited by C. Ratledge \& J. Stanford. London: Academic Press.

Seifter, S., Dayton, S., Novic, B. \& Muntwyler, E. (1950). The estimation of glycogen with anthrone reagent. Archives of Biochemistry 25, 191-200.

Smith, M. R., de HaAn, A. \& de Bont, J. A. M. (1993). The effect of calcium alginate entrapment on the physiology of Mycobacterium sp. strain E3. Applied Microbiology and Biotechnology 38, 642-648.

StiRling, D. I. \& Dalton, H. (1979). The fortuitous oxidation and cometabolism of various carbon compounds by whole-cell suspensions of Methylococcus capsulatus (Bath). FEMS Microbiology Letters 5, 315-318.

van Urk, H., Postma, E., Scheffers, W. A. \& van Dijken, J. P. (1989). Glucose transport in Crabtree-positive and Crabtree-negative yeasts. Journal of General Microbiology 135, 2399-2406.

Weber, F. J., van Berkel, W. J. H., Hartmans, S. \& de Bont, J. A. M. (1992). Purification and properties of the NADH reductase component of alkene monooxygenase from Mycobacterium strain E3. Journal of Bacteriology 174, 3275-3281.

Wiegant, W. M. \& DE Bont, J. A. M. (1980). A new route for ethylene glycol metabolism in Mycobacterium E44. Journal of General Microbiology 120, 325-331.

Winder, F. G. \& RoONEY, S. A. (1970). Effect of nitrogenous components of the medium on the carbohydrate and nucleic acid content of Mycobacterium tuberculosis BCG. Journal of General Microbiology 63, 29-39.

Yokobayashi, K., Misaki, A. \& Harada, T. (1970). Purification and properties of Pseudomonas isoamylase. Biochimica et Biophysica Acta 212, 458-469. 